\title{
PENGARUH TAKARAN PUPUK FOSFOR (P) TERHADAP PERTUMBUHAN DAN HASIL BEBERAPA VARIETAS TANAMAN PADI (Oryza sativa L.)
}

\section{THE EFFECT OF PHOSPHOR (P) FERTILIZER MEASURES ON THE GROWTH AND YIELD OF SOME VARIETIES RICE PLANT (Oryza sativa L.)}

\author{
Eli Rosalina ${ }^{1}$, Yogi Nirwanto ${ }^{2}$ \\ ${ }^{1}$ UPTD Pertanian Pakisjaya, Dinas Pertanian Kabupaten Karawang \\ ${ }^{2}$ Program Studi Agroteknologi Fakultas Pertanian Universitas Siliwangi \\ Jalan Siliwangi No. 24 Kode Pos 46115 Tasikmalaya \\ Korespondensi : yogi.nirwanto@unsil.ac.id
}

\begin{abstract}
ABSTRAK
Padi merupakan tanaman pangan yang menghasilkan makanan pokok penduduk Indonesia. Peningkatan kualitas tanaman sangatlah penting dilakukan, salah satunya melalui pemberian Pupuk Posfor $(\mathrm{P})$ dan pemilihan varietas tanaman merespon pemupukan terhadap pertumbuhan. Penelitian bertujuan untuk mengetahui pengaruh pemberian takaran pupuk $\mathrm{P}$ terhadap pertumbuhan dan hasil beberapa varietas tanaman padi. Penelitian dilaksanakan di lahan sawah di Desa Telukbuyung, Kecamatan Pakisjaya, kabupaten Karawang. Rancangan yang digunakan dalam penelitian adalah Rancangan Split Plot terdiri dari petak utama varietas terdiri dari empat taraf yaitu: v1 (varietas Ciherang), v2 (varietas Mekongga), v3 (varietas inpari 33), v4 (varietas Cilamaya Muncul). Anak petak takaran pupuk $\mathrm{P}$ (biost $\mathrm{P}$ ) terdiri dari empat taraf yaitu: d0 (tanpa pupuk P), d1 (150 kg ha $\left.{ }^{-1}\right), \mathrm{d} 2\left(300 \mathrm{~kg} \mathrm{ha}^{-1}\right), \mathrm{d} 3\left(450 \mathrm{~kg} \mathrm{ha}^{-1}\right)$. Hasil percobaan menunjukkan terjadi interaksi antara varietas dengan takaran pupuk $\mathrm{P}$ terhadap bobot gabah kering panen (GKP) per rumpun. Hasil bobot gabah kering panen (GKP) per rumpun sebesar 572,60 gram diperoleh melalui varietas Mekongga dengan takaran dosis pupuk P $300 \mathrm{~kg} \mathrm{ha}^{-1}$.
\end{abstract}

Kata kunci: Pupuk P, P Tanaman, Padi

\begin{abstract}
Rice is a food plant that produces the staple food of the Indonesian population. Improving plant quality is very important, one of which is through the provision of phosphorus fertilizer $(\mathrm{P})$ and the selection of plant varieties that respond to fertilization to growth. The aim of the study was to determine the effect of the dose of $\mathrm{P}$ fertilizer on the growth and yield of several rice varieties. The research was conducted in rice fields in Telukbuyung Village, Pakisjaya District, Karawang Regency. The design used in this study was a split plot design consisting of main plots of varieties consisting of four levels, namely: v1 (Ciherang variety), v2 (Mekongga variety), v3 (inpari 33 variety), v4 (Cilamaya Muncul variety). Subsidiary plots of $\mathrm{P}$ fertilizer (biost P) consisted of four levels, namely: d0 (without P fertilizer), d1 (150 kg ha-1), d2 (300 kg ha $\left.{ }^{-1}\right), \mathrm{d} 3$ $\left(450 \mathrm{~kg} \mathrm{ha}^{-1}\right)$. The results of the experiment showed that there was an interaction between the varieties and the $\mathrm{P}$ fertilizer dosage on the dry grain weight (GKP) per hill. The yield of harvested dry grain weight (GKP) per clump of 572,60 grams was obtained through the Mekongga variety with a fertilizer dosage rate of $\mathrm{P} 300 \mathrm{~kg} \mathrm{ha}^{-1}$.
\end{abstract}

Keywords : P Fertilizer, P Plants, Rice 


\section{PENDAHULUAN}

Padi menjadi komponen utama dalam ketahanan pangan nasional serta menentukan stabilitas nasional. Pada tahun 2007, konsumsi pangan sebagai sumber energi khususnya beras di atas $60 \%$ angka kecukupan gizi (AKG) dan konsumsi beras perkapita masih sangat tinggi yaitu sekitar $139,15 \mathrm{~kg} /$ tahun (Nainggolan, 2008). Hal ini menandakan bahwa kebutuhan padi sangat di perlukan untuk menopang kebutuhan gizi masyarakat Indonesia.

Penggunaan benih unggul menunjukkan kontribusi terbesar terhadap produksi dibandingkan dengan penerapan teknologi lainnya (Saryoko, 2009). Disisi lain, nilai biaya benih hanya sekitar $5 \%$ dari total biaya input produksi padi (Kementerian Pertanian, 2010). Dikaji lebih lanjut, penggunaan benih unggul merupakan komponen intensifikasi pertanian paling mudah dilakukan untuk mendukung peningkatan produksi padi.

Program peningkatan ketahanan pangan diarahkan untuk dapat memenuhi kebutuhan pangan masyarakat di dalam negeri dari produksi pangan nasional. Seiring peningkatan laju pertumbuhan penduduk, kebutuhan beras juga semakin meningkat. Ini merupakan tantangan bagi petani untuk mencari pilihan teknologi yang mampu mencukupi kebutuhan pangan dengan kualitas baik dan menyehatkan tetapi tidak menimbulkan kerusakan lingkungan (BPS, 2013).

Usaha pengembangan tanaman pangan di Jawa Barat, khususnya padi terkonsentrasi pada kabupaten sentra pengembangan beras, Kabupeten Karawang sebagai daerah pemasok pangan ke kabupaten lainnya di Jawa Barat (Badan Pusat Statistik, 2014). Oleh karena itu diharapkan produksi dan produktivitas padi tetap meningkat, baik dari segi kuantitas maupun kualitas serta dapat meminimalkan pasokan beras dari luar Jawa Barat.

Upaya pemerintah untuk mencapai swasembada beras yang telah dicapai semakin sulit, hal ini disebabkan semakin menyusutnya lahan-lahan subur karena beralih fungsi menjadi pemukiman dan usaha industri (Balai Besar Tanaman Padi, 2010). Usaha yang dapat dilakukan guna mencapai swasembada beras adalah meningkatkan produktivitas padi atau dengan penanaman varietas unggul dan melakukan pemupukan (Makarim et al., 2007).

Keunggulan varietas lokal yang tidak dimiliki oleh varietas unggul yaitu mempunyai sifat genetik yang tahan terhadap kondisi cekaman biotik berupa hama dan penyakit tanaman atau kondisi abiotik berupa kondisi cuaca yang tidak menguntungkan dan kandungan Besi $(\mathrm{Fe})$ dan Aluminium (Al) didalam tanah yang tinggi (Daradjat, Susanto dan Suprihatno, 2003). Varietas tersebut umumnya tidak efisien dalam penggunaan $\mathrm{P}$ karena dirakit pada kondisi $\mathrm{P}$ optimum. Jika varietas ditanam pada kondisi $\mathrm{P}$ rendah maka hasilnya menurun drastis (Bobihoe, 2009).

Perlu usaha peningkatan efisiensi pemupukan. Salah satunya adalah dengan penggunaan pupuk $\mathrm{P}$ dengan dosis tinggi yang mampu merangsang pemecahan ikatan ikatan $\mathrm{P}$ dengan $\mathrm{Al}, \mathrm{Ca}$ dan $\mathrm{Mg}$ sehingga $\mathrm{P}$ yang semula tidak tersedia di dalam tanah menjadi tersedia bagi tanaman (Estiaty, 2014).

Penelitian ini bertujuan untuk mengetahui pengaruh interaksi antara pemberian $\mathrm{P}$ terhadap $\mathrm{P}$ tersedia tanah, pertumbuhan dan hasil beberapa varietas tanaman padi dan memperoleh takaran $\mathrm{P}$ yang tepat yang dapat memberikan hasil maksimal terhadap pertumbuhan dan hasil tiap varietas tanaman padi. 


\section{BAHAN DAN METODE}

Penelitian bersifat verifikatif dengan menggunakan metode eksperimen di lapangan. Percobaan dilaksanakan di Desa Telukjaya Kecamatan Pakisjaya Kabupaten Karawang. Jenis tanah Alluvial serta tipe dan iklim tempat percobaan berdasarkan perhitungan data curah hujan 10 tahun terakhir termasuk tipe E menurut klasifikasi curah hujan Schmidt and Ferguson (1951). Percobaan dilaksanakan pada musim hujan selama lima bulan, yaitu mulai dari bulan Februari sampai dengan bulan Juni 2020.

Bahan yang digunakan dalam percobaan ini antara lain adalah benih padi Varietas Ciherang, Cilamaya Muncul, Mekongga dan Inpari 33 (Deskripsi masing masing varietas tertera di Lampiran 2. Pupuk Urea (46\% N), $\mathrm{KCl}\left(60 \% \mathrm{~K}_{2} \mathrm{O}\right)$, pupuk $\mathrm{P}_{2} \mathrm{O}_{5}$ Organik Biost P (13\% P), Fungisida Amristartof 250 EC, Insektisida Virtako $300 \mathrm{SC}$, Prevathon 50 SC, Furadan 3G, Samponint, Cruiser 25 ST.

Rancangan lingkungan yang digunakan dalam percobaan adalah rancangan Petak terbagi (Split Plot Design). Petak utama (Main Plot Faktor) adalah varietas tanaman padi (v) yang terdiri dari empat taraf :

$$
\begin{aligned}
& \mathrm{v}_{1}=\text { Ciherang } \\
& \mathrm{v}_{2}=\text { Cilamaya Muncul } \\
& \mathrm{v}_{3}=\text { Mekongga } \\
& \mathrm{v}_{4}=\text { Inpari } 33
\end{aligned}
$$

Anak petak (sub plot faktor) adalah Takaran Pupuk P Organik Bios P yang terdiri dari empat taraf :

$$
\begin{aligned}
& \mathrm{d}_{0}=0 \mathrm{~kg} \mathrm{ha}^{-1} \\
& \mathrm{~d}_{1}=150 \mathrm{~kg} \mathrm{ha}^{-1} \\
& \mathrm{~d}_{2}=300 \mathrm{~kg} \mathrm{ha}^{-1} \\
& \mathrm{~d}_{3}=450 \mathrm{~kg} \mathrm{ha}^{-1}
\end{aligned}
$$

Kombinasi kedua faktor tersebut diulang masing-masing sebanyak dua kali dengan demikian jumlah plot percobaan adalah $4 \times 4 \times 2=32$ plot percobaan. Setiap plot berukuran $6 \mathrm{~m} \times 3$ meter.

\section{Pengamatan Penunjang}

Variabel dalam percobaan terdiri dari Variabel bebas (independent variable) yaitu terdiri dari varietas tanaman padi sebagai petak utama (V) dan takaran pupuk P (D) sebagai anak petak, dan diulang sebanyak tiga kali, sehingga variabel bebas dalam satu ulangan terdapat 16 kombinasi perlakuan dan variabel terikat (dependent variable) yaitu berupa respon tanaman akibat perlakuan, karakteristik pertumbuhan, dan komponen hasil.

a. Analisis Tanah Percobaan

Analisis Tanah Sebelum Percobaan dengan mengambil sampel pada tanah secara komposit, kemudian analisis kimia dilakukan di Laboratorium Kimia Agro, Lembang untuk mengetahui komposisi unsur hara yang terdapat dalam tanah di lahan percorbaan.

b. Keadaan Cuaca Selama Percobaan

Pengamatan kaeadaan cuaca selama percobaan dilakukan terhadap suhu, kelembaban relatif harian dan curah hujan harian selama percobaan.

c. Hama Penyakit yang menyerang tanaman

Pengamatan serangan OPT meliputi kelompok hama dan penyakit dilakukan dengan mengamati gejala serangan yang tampak secara visual pada pertanaman dan mengidentifikasi jenis hama atau penyebab penyakit (pathogen) yang ditemukan.

\section{Pengamatan Utama}

Pengamatan utama diuji secara stasitistik meliputi pengamatan :

a. Tinggi Tanaman

Tinggi diukur dari pangkal batang sampai ujung bagian tananan tertinggi. Pada umur 14, 28, 42 dan 56 hst. Data tinggi tanaman diperoleh dari rata-rata tinggi tanaman dari 10 tanaman contoh pada tiap petak percobaan. 


\section{b. Jumlah Anakan per Rumpun}

Jumlah anakan per rumpun dari 10 tanaman pada setiap petak percobaan. Pada umur 14, 28, 42, dan 56 hst.

c. Jumlah Malai per Rumpun

Jumlah malai per rumpun adalah ratarata banyaknya malai dalam satu rumpun dari 10 tanaman contoh pada tiap petak percobaan.

\section{d. Jumlah Gabah per Malai}

Rata-rata jumlah bulir gabah dari setiap malai dari tanaman contoh. Gabah isi dan gabah yang hampa. Pengamatan dilakukan pada saat panen.

e. Persentase Gabah Isi

Perbandingan antara jumlah gabah isi per malai dibagi jumlah gabah total per malai dikalikan $100 \%$.

Persentase Gabah Isi $=\frac{\text { jumlah gabah isi per malai }}{\text { jumlah gabah total per malai }} \times 100 \%$

\section{f. Bobot Gabah Kering Panen per Rumpun (gabah Isi)}

Berat gabah isi dalam satu rumpun padi yang di timbang berdasaran hasil jumlah bobot per rumpun. Pengukuran bobot kering panen per rumpun dilakukan pada saat pemanenan dan ditimbang dalam satu rumpun tanaman.

g. Bobot Gabah Kering Panen per Petak

Berat gabah isi dalam satu petak perobaan yang di timbang berdasaran hasil jumlah bobot per petak tanaman. Pengukuran dilakukan dengan menimbang hasil gabah dalam satu petak. Pengukuran dilakukan menggunakan alat timbangan.

h. Bobot Gabah Kering Giling per Rumpun dan per Petak

Hasil bobot gabah yang telah dikeringkan dan dihitung dengan menimbang hasil GKG pada kadar air $14 \%$.

\section{i. Bobot 1000 Butir Gabah Isi}

Rata-rata bobot 1000 butir gabah pada setiap petak percobaan. Bulir gabah yang telah dihitung dan dinyatakan dalam satuan gram, kemudian dikonversikan ke dalam kadar air baku $14 \%$. Juga dinyatakan dalam satuan gram, Bobot 1000 butir gabah isi diambil dari 10 rumpun sampel dari setiap petak percobaan. Rumus yang digunakan adalah sebagai berikut

Bobot 1000 butir $=\frac{100-K A}{100-14 \%} x$ bobot 1000 butir $(g)$ GKP

$\mathrm{KA}=$ Kadar air gabah kering panen

GKP = Gabah kering panen

Sumber data sekunder dan data primer. Data sekunder dari data pustaka dengan mempelajari penemuan para ahli yang dituangkan dalam buku dan karya ilmiah atau jurnal penelitian terkait yang dapat dipertanggung-jawabkan. Sedangkan data primer diperoleh melalui observasi (pengamatan) terhadap varietas tanaman padi akibat pemberian Takaran pupuk $\mathrm{P}$ terhadap $\mathrm{P}$ tersedia tanah. Adapun respon tanaman yang diamati (diukur) yaitu : karakter pertumbuhan, komponen hasil dan hasil yang telah diuraikan terdahulu.

\section{Pelaksanaan Percobaan}

Dilakukan dengan berbagai teknik pengambilan data. Kegiatan penelitian meliputi kegiatan pengolahan tanah, persemaian, penanaman, penyulaman, pemupukan, pengairan, pengendalian hama dan penyakit, panen dan pengamatan.

a. Pengolahan Tanah

Pengolahan pertama dan kedua menggunakan bajak rotari dengan kedalaman 25 sampai $30 \mathrm{~cm}$. Selang satu minggu dilakukan pengolahan tanah yang kedua dan pengolahan tanah ketiga dilakukan berselang waktu satu minggu dan menggunakan alat garu. Dibuat petakpetakan dengan ukuran $3,5 \mathrm{~m}$ x $6 \mathrm{~m}$. Setelah petakan tanah dirapihkan sampai tanah dalam kondisi siap ditanami.

\section{b. Perlakuan Benih dan Persemaian}

Persemaian basah dengan tanah yang digunakan telah dibajak dan diratakan 
kemudian dibuat bedengan. Luas tempat persemaian yang digunakan yaitu kurang lebih $50 \mathrm{~m}^{2}$ dibuat 3 bedengan. Benih padi yang sudah dipersiapkan direndam selama 24 jam kemudian diberi perlakuan seed treatment Cruiser 25 ST dengan dosis 5 $\mathrm{ml} / \mathrm{kg}$ benih, selanjutnya ditiriskan selama 24 jam. Pemberian air dilakukan setelah benih melekat dengan tanah yaitu pada umur dua hari setelah sebar.

\section{c. Penanaman dan Penyulaman}

Setelah berumur 18 hari setelah semai sebanyak 2 benih per lubang tanam dengan jarak tanam $25 \mathrm{~cm} \times 25 \mathrm{~cm}$. Penyulaman pada umur 7 hari dengan menggunakan benih padi cadangan, ditanam dekat lokasi percobaan dengan umur benih yang sama.

\section{d. Pemupukan}

Dosis pupuk organik dan anorganik dengan dosis rekomendasi padi sawah spesifik lokasi berdasarkan Permentan No. 40/permentan/OT.140.04/2007.

Rekomendasi pupuk Organik dan anorganik yaitu $2 \mathrm{t} /$ ha pupuk organik, $275 \mathrm{~kg} \mathrm{ha}^{-1}$ urea, dan $50 \mathrm{~kg} \mathrm{ha}^{-1} \mathrm{KCl}$, adapun takaran $\mathrm{P}$ yang digunakan adalah sesuai dengan perlakuan yang telah ditentukan .

Pemupukan anorganik (Urea, SP36 dan $\mathrm{KCl}$ ) anorganik dilakukan sebanyak 2 kali. Pemberian pertama dilakukan pada saat 7 hari setelah tanam (hst) sebanyak 1/3 dosis urea $(275 \mathrm{~kg} /$ petak $)$ ditambah $1 / 2$ dosis pupuk $\mathrm{KCl}$ ( $50 \mathrm{~kg} /$ petak) dan $1 / 2$ dosis Bios P. Pemberian pupuk anorganik kedua dilakukan pada $20 \mathrm{hst}$, pupuk yang diberikan yang terdiri dari $1 / 3$ dosis urea. Pemberian pupuk anorganik ketiga dilakukan pada umur 42 hst. yang terdiri dari $1 / 3$ dosis pupuk urea dan $1 / 2$ dosis pupuk $\mathrm{KCl}$ dan $1 / 2$ bagian Bios $\mathrm{P}$.

e. Penyiangan dan Pengairan

Penyiangan mekanis dengan mencabut gulma yang tumbuh. Penyiangan dilakukan 2 kali penyiangan yaitu padda umur $14 \mathrm{hst}$ dan 40 hst. Setelah berselang 3 hari, tanaman diairi sampai kondisi tanah tergenang. Pada pemupukan, lahan dikeringkan, setelah pemupukan kondisi tersebut dibiarkan selama 3 hari, diharapkan unsur hara meresap ke akar tanaman dan tanah. Setelah itu kondisi pertanaman tergenang.

f. Pengendalian Hama dan Penyakit Tanaman

Pengendalian OPT meliputi pengendalian hama, dan penyakit. Berdasarkan data yang diperoleh bahwa daerah percobaan merupakan daerah endemik hama penggerek batang (Tryporyza Spp), sehingga untuk mengindari serangan yang parah dilakukan tindakan pencegahan menggunakan insektisida dimehipo $500 \mathrm{ml} / \mathrm{l}$.

g. Panen

Pemanenan dilakukan pada saat pertanaman padi di lapangan telah memasuki fase masak secara fisiologis (85\%-90\%) yaitu dicirikan dengan keadaan gabah pada malai telah menguning merata.

\section{Analisis Data dan Uji Lanjut}

Guna mengetahui dan menguji pengaruh takaran pemupukan $\mathrm{P}$ terhadap pertumbuhan dan hasil beberapa varietas tanaman padi, data hasil pengamatan dianalisis menggunakan sidik ragam (anova) berdasarkan model linier rancangan petak terbagi (split plot design).

Jika hasil analisis ragam menunjukkan perbedaan yang nyata pada taraf $\alpha=5 \%$, maka untuk mengetahui perbedaan pengaruh di antara perlakuan analisis data dilanjutkan dengan menggunakan Uji Beda Nyata Terkecil (BNT)/Least Significant Different (LSD) pada taraf nyata 5\% .

\section{HASIL DAN PEMBAHASAN}

\section{Pengamatan Penunjang}

a. Analisis Tanah Sebelum Percobaan

Dari hasil analisis tanah sebelum percobaan menunjukkan bahwa kondisi tanah mempunyai kandungan C-organik 
sangat rendah, $\mathrm{P}_{2} \mathrm{O}_{5}(\mathrm{HCl} 25 \%)$ tinggi, $\mathrm{K}_{2} \mathrm{O}$ ( $\mathrm{HCl} 25 \%)$ sangat rendah, kapasitas tukar kation (KTK) rendah, kejenuhan basa (KB) tinggi dan $\mathrm{P}_{2} \mathrm{O}_{5}$ tersedia termasuk rendah.

b. Curah hujan, suhu, dan kelembaban selama percobaan

Jumlah curah hujan, suhu dan kelembaban udara pada periode percobaan tidak mengalami perubahan cukup berarti. Rata-rata suhu harian pada bulan Maret Sebesar 39,5 dengan kisaran rata-rata $24,5^{\circ} \mathrm{C}-34,5^{\circ} \mathrm{C}$, pada bulan april sebesar 39,7 dengan kisaran rata-rata $24,7^{\circ} \mathrm{C}$ $34,5^{\circ} \mathrm{C}$. Mei sebesar $30,4^{\circ} \mathrm{C}$ dengan kisaran suhu rata-rata $25,1^{\circ} \mathrm{C}-34,5^{\circ} \mathrm{C}$, rata-rata kelembaban udara sebesar $82,8 \%$, dan curah hujan sebesar $98 \mathrm{~mm}$. Pada bulan Juni rata-rata suhu harian sebesar $30,4^{\circ} \mathrm{C}$, kelembaban udara $83,1 \%$ dan curah hujan sebesar $67 \mathrm{~mm}$.

c. Keadaan Umum pertanaman Padi

Pertumbuhan tanaman pada percobaan relatif baik, ditunjukan oleh daya tumbuh tanaman padi di petak percobaan mencapai 95\%. Rata-rata jumlah anakan produktif 12 sampai 25 anakan. Panen umur 90 sampai 105 HST, dengan menggunakan sabit bergerigi, kemudian dirontokkan.

Organisme pengganggu tanaman (OPT) yang menyerang selama percobaan antara lain Siput Murbai (Pomacea caniculata), Wereng Batang Coklat (Nilaparvata lugens), Tikus (Rattus rattus argentiventer), Burung Bondol (Lonchura maja leucocephala) dan Penyakit Blas (Pycularia oryzae). Hama Siput Murbei (Pomacea caniculata) ditemukan menyerang pada umur 1 HST sampai dengan umur 20 HST dengan rata intensitas serangan $<4 \%$. Siput Murbai menyerang dengan cara memakan batang padi muda. Pengendalian dilakukan dengan mengambil satu persatu pada petak percobaan. Sedangkan penyakit Blas (Pycularia oryzae) menyerang pada umur 25 HST sampai dengan 50 HST dengan rata-rata intensitas $<5 \%$. Penyakit blas disebabkan oleh jamur. Menyerang pada daun berupa bercak coklat berbentuk belah ketupat. pengendalian dilakukan dengan penyemprotan agen hayati Corryne bacterium umur $35 \mathrm{HST}$.

Musuh alami yang ditemukan di areal penelitian yaitu laba-laba (Lycosa sp), Bobotolan (Ophionea sp) dan Kumbang (Coccinella sp). Keberadaan musuh alami membantu dalam upaya pengendalian hama wereng batang coklat. Sedangkan gulma yang tumbuh diantaranya teki (Cyperus rotundus L), Kakawatan (Cynodon dactylon L Pers) dan Eceng (Monochoria vaginalis) dengan populasi gulma tergolong rendah. Walaupun pertumbuhan gulma ini sangat sedikit tetapi tetap dilakukan penyiangan yang disesuaikan dengan pemeliharaan yaitu pada umur 14 HST dan $40 \mathrm{HST}$, penyiangan dilakukan dengan cara mencabuti gulma menggunakan tangan tanpa alat penyiangan atau herbisida.

\section{Pengamatan Utama}

\section{a. Tinggi Tanaman}

Hasil analisis statistik terhadap tinggi tanaman padi menunjukkan efek mandiri pada petak utama yaitu berbeda tidak berpengaruh terhadap tinggi tanaman padi umur 14 HST, sedangkan pada tinggi tanaman padi umur 28 HST, 42 HST dan 56 HST memperlihatkan pengaruhnya yang berbeda nyata. Sedangkan pada tinggi tanaman padi umur 28 HST dan 56 HST, pada varietas Cilamaya Muncul (v4) memberikan tinggi tanaman yang tertinggi dan berbeda nyata dibandingkan dengan perlakuan varietas Ciherang (v1), varietas Mekongga (v2) dan varietas Inpari 33 (v3), tetapi pada tinggi tanaman padi umur 42 HST, pada varietas Cilamaya Muncul (v4) berbeda tidak nyata dengan varietas ciherang (v1). Interaksi antara varietas dengan dosis pupuk $\mathrm{P}$ terhadap tinggi tanaman dengan hasil analisis efek mandiri, disajikan dalam Tabel 1 dibawah ini. 
Tabel 1. Pengaruh Takaran Pupuk $\mathrm{P}$ terhadap Tinggi Tanaman Umur 14, 28, 42 dan 56 HST pada Beberapa Varietas Tanaman Padi (Oryza Sativa L.) Rata-rata Tinggi Tanaman

\begin{tabular}{ll|l|l|l} 
Perlakuan 14 HST & 28 HST & 42 HST & 56 HST \\
\hline
\end{tabular}
--- $\mathrm{cm}$---

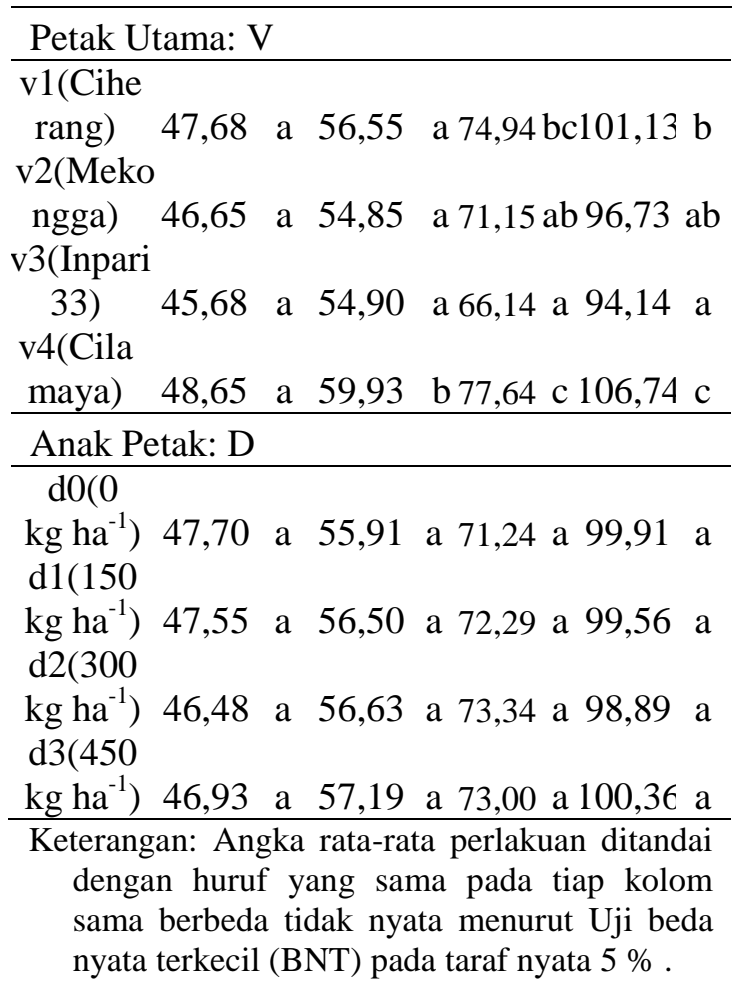

Varietas Cilamaya Muncul berbeda nyata sesuai dengan deskripsi varietas merupakan varietas yang mempunyai tinggi lebih dari $100 \mathrm{~cm}$, bentuk daun tegak, muka daun tegak dan bentuk tanaman tegak (BB Padi, 2010). Perbedaan pertumbuhan tanaman yang signifikan antar varietas tidak terlepas dari genetik masing-masing varietas tanaman padi sesuai deskripsi varietas.

b. Jumlah Anakan

Penggunaan dosis pupuk $\mathrm{P}$ berbeda tidak memperlihatkan pengaruhnya terhadap jumlah anakan umur 14 HST dan28 HST, pada jumlah anakan umur 42 HST dan 56 HST memperlihatkan pengaruhnya yang berbeda nyata. Jumlah anakan umur 42 HST dan 56 HST, dosis pupuk P $300 \mathrm{~kg} \mathrm{ha}^{-1}$ (d2) dan $450 \mathrm{~kg} \mathrm{ha}^{-1}$ (d3) memberikan hasil yang lebih dan berbeda nyata dibandingkan dengan perlakuan tanaman yang tidak diberikan pupuk P (d0). Sedangkan pada perlakuan pemberian dosis pupuk $\mathrm{P} 150 \mathrm{~kg}$ ha $^{-1}$ (d1) tidak memberikan hasil yang berbeda nyata dengan tanaman yang tidak diberikan dosis pupuk $\mathrm{P}$ (d0). Interaksi antara varietas dengan dosis pupuk $P$ terhadap jumlah anakan dengan hasil analisis efek mandiri masing-masing pengaruh perlakuan pada Tabel 2 .

Tabel 2. Pengaruh Takaran Pupuk P terhadap Jumlah Anakan Umur Per Rumpun umur 14, 28, 42 dan 56 HST Beberapa Varietas Tanaman Padi (Oryza Sativa L.)

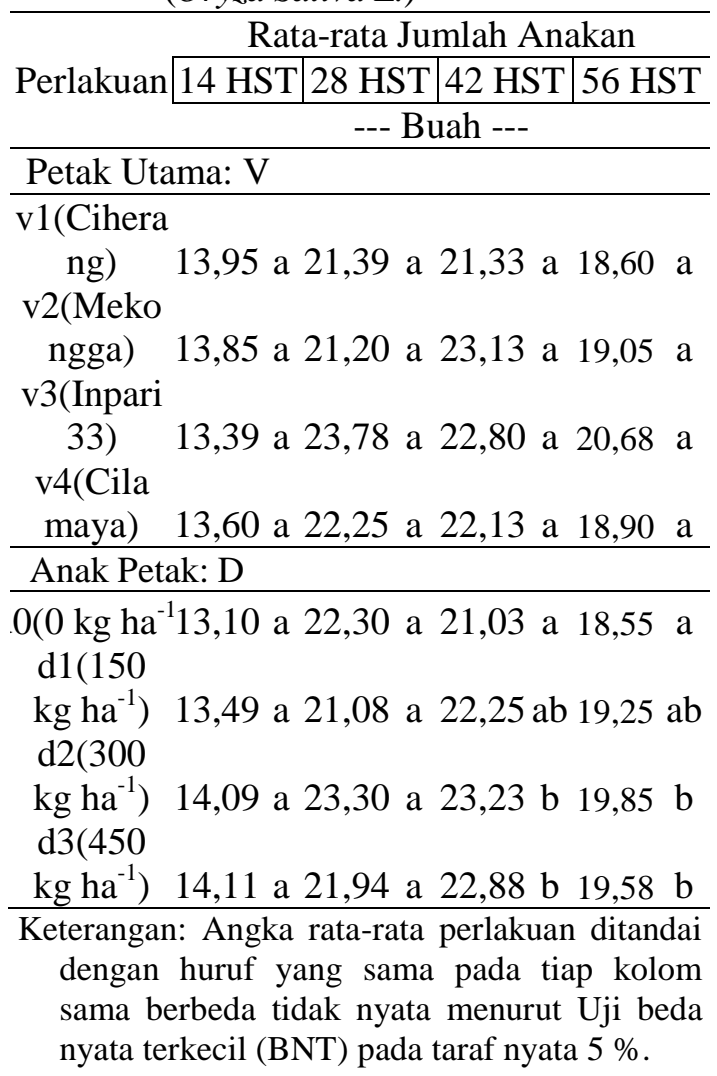

Fosfor termasuk unsur hara penting penyusun adenosin trifosfat (ATP) yang secara langsung berperan dalam proses penyimpanan dan transfer energi, terkait proses metabolisme tanaman (Dobermann and Fairhurst, 2000; dalam Sarlan dan Sembiring, 2006). Hara P memacu pembentukan akar dan penambahan jumlah anakan, serta berfungsi mempercepat pembungaan dan pemasakan buah. 


\section{Komponen Hasil}

a. Jumlah Malai Per Rumpun

Berdasarkan hasil analisis data menunjukkan bahwa tidak terjadi interaksi antara varietas dengan dosis pupuk $\mathrm{P}$ terhadap jumlah malai per rumpun dengan hasil analisis efek mandiri pada masing - masing pengaruh perlakuan. Berdasarkan Tabel 4, menunjukkan bahwa efek mandiri pada anak petak penggunaan dosis pupuk $\mathrm{P}$ berbeda maka adanya pengaruh terhadap jumlah malai per rumpun. Pada dosis pupuk P $300 \mathrm{~kg} \mathrm{ha}^{-1}(\mathrm{~d} 2)$ memberi hasil jumlah malai per rumpun tertinggi dan berbeda nyata dengan dosis pupuk P $150 \mathrm{~kg} \mathrm{ha}^{-1}(\mathrm{~d} 1)$, dosis pupuk P 450 $\mathrm{kg} \mathrm{ha}^{-1}(\mathrm{~d} 3)$, tanpa pemberian dosis pupuk $\mathrm{P} 0$ $\mathrm{kg} \mathrm{ha}^{-1}(\mathrm{~d} 0)$.

Tabel 3. Pengaruh Takaran Pupuk P terhadap Jumlah Malai Per Rumpun pada Beberapa Varietas Tanaman Padi (Oryza Sativa L.)

\begin{tabular}{ccc}
\hline \multirow{2}{*}{ Perlakuan } & \multicolumn{2}{c}{$\begin{array}{c}\text { Rata-rata Jumlah } \\
\text { Malai Per Rumpun }\end{array}$} \\
\cline { 2 - 3 } & \multicolumn{2}{c}{-- malai --- } \\
\hline Petak Utama: V & & \\
\hline v1(Ciherang) & 13,26 & $\mathrm{a}$ \\
v2(Mekongga) & 14,04 & $\mathrm{a}$ \\
v3(Inpari 33) & 14,54 & $\mathrm{a}$ \\
v4(Cilamaya) & 13,74 & $\mathrm{a}$ \\
\hline Anak Petak: D & & \\
\hline d0(0 kg ha-1) & 12,81 & $\mathrm{a}$ \\
d1(150 kg ha $\left.{ }^{-1}\right)$ & 14,04 & $\mathrm{~b}$ \\
d2(300 $\left.\mathrm{kg} \mathrm{ha}^{-1}\right)$ & 14,71 & $\mathrm{c}$ \\
d3(450 $\left.\mathrm{kg} \mathrm{ha}^{-1}\right)$ & 14,01 & $\mathrm{~b}$ \\
\hline
\end{tabular}

Keterangan: Angka rata-rata perlakuan yang ditandai dengan huruf yang sama berbeda tidak nyata menurut Uji beda nyata terkecil (BNT) pada taraf nyata $5 \%$.

Pemberian pupuk $\mathrm{P}$ berperan dalam pembentukan malai, takaran pupuk $\mathrm{P}$ yang optimum menghasilkan daun yang optimum sehingga distribusi cahaya matahari akan merata. Pemupukan P lahan sawah seringkali dilakukan secara intensif, seringkali tanpa memperhatikan status hara $\mathrm{P}$ tanah.
Pemupukan ini dilakukan pada setiap musim tanam, sehingga timbunan $P$ di dalam tanah yang sesungguhnya dapat dimanfaatkan sebagai sumber hara $\mathrm{P}$ bagi tanaman padi. Unsur fosfor $(\mathrm{P})$ termasuk unsur esensial bagi tanaman karena merupakan faktor pembatas yang mempengaruhi pertumbuhan dan produksi tanaman. Unsur P berperan dalam mendorong pertumbuhan dan perkembangan akar, memicu pembungaan dan pematangan buah terutama pada kondisi iklim rendah.

\section{b. Jumlah Gabah Isi Per Malai}

Hasil analisis data menunjukkan tidak terjadi interaksi antara varietas dengan dosis pupuk $\mathrm{P}$ terhadap jumlah gabah isi per malai pada hasil analisis efek mandiri masingmasing pengaruh perlakuan disajikan pada Tabel 4.

Tabel 4. Pengaruh Takaran Pupuk P terhadap Jumlah Gabah Isi Per Malai Beberapa Varietas Tanaman Padi (Oryza Sativa L.)

\begin{tabular}{ccc}
\hline \multirow{2}{*}{ Perlakuan } & $\begin{array}{c}\text { Rata-rata Jumlah } \\
\text { Gabah Isi Per Malai }\end{array}$ \\
\cline { 2 - 3 } & \multicolumn{2}{c}{---- Butir ----- } \\
\hline Petak Utama: V & & \\
\hline v1 (Ciherang) & 130,91 & $\mathrm{a}$ \\
v2 (Mekongga) & 137,34 & $\mathrm{a}$ \\
v3 (Inpari 33) & 140,93 & $\mathrm{a}$ \\
v4 (Cilamaya) & 131,31 & $\mathrm{a}$ \\
\hline Anak Petak: D & & \\
\hline d0(0 kg ha $\left.{ }^{-1}\right)$ & 122,67 & $\mathrm{a}$ \\
d1(150 kg ha & 135,37 & $\mathrm{~b}$ \\
d2(300 $\left.\mathrm{kg} \mathrm{ha}^{-1}\right)$ & 143,71 & $\mathrm{c}$ \\
d3(450 $\left.\mathrm{kg} \mathrm{ha}^{-1}\right)$ & 138,73 & $\mathrm{bc}$
\end{tabular}

Keterangan: Angka rata-rata perlakuan yang ditandai dengan huruf yang sama pada tiap kolom (huruf kecil) tidak berbeda nyata menurut Uji beda nyata terkecil (BNT) pada taraf nyata $5 \%$.

Berdasarkan Tabel 5, Menunjukkan bahwa efek mandiri pada anak petak penggunaan dosis pupuk $\mathrm{P}$ yang berbeda memperlihatkan adanya pengaruh terhadap jumlah gabah isi per malai. Pada dosis pupuk P $300 \mathrm{~kg} \mathrm{ha}^{-1}$ (d2) memberikan hasil jumlah gabah isi per 
malai tertinggi dan berbeda nyata dengan hasil jumlah gabah per malai pada dosis pupuk $\mathrm{P}$ $150 \mathrm{~kg} \mathrm{ha}^{-1}$ (d1) dan tanpa pemberian dosis pupuk P $0 \quad \mathrm{~kg} \mathrm{ha}^{-1}(\mathrm{~d} 0)$, tetapi tidak berbeda nyata dengan hasil jumlah gabah isi per malai pada dosis pupuk P $450 \mathrm{~kg} \mathrm{ha}^{-1}$ (d3).

Pemupukan fosfor dan kalium sangat penting untuk meningkatkan produksi dan hasil panen tanaman padi. Fosfor sangat berguna atau penting dalam pembentukan pati pada bulir gabah padi, sedangkan kalium berguna untuk memperkokoh batang tanaman sehingga tanaman tidak mudah rebah (Rosmarkan dan Yuwono, 2002).

\section{c. Persentase Gabah Isi}

Berdasarkan hasil analisis data menunjukkan bahwa tidak terjadi interaksi antara varietas dengan dosis pupuk $\mathrm{P}$ terhadap persentase gabah isi dan tidak terjadi efek mandiri pada petak utama (varietas) maupun pada anak petak (dosis pupuk), disajikan pada Tabel 5 .

Tabel 5. Pengaruh Takaran Pupuk P terhadap Persetase Gabah Isi pada Beberapa Varietas Tanaman Padi (Oryza Sativa L.)

\begin{tabular}{ccc}
\hline \multirow{2}{*}{ Perlakuan } & \multicolumn{2}{c}{ Persentase Gabah Isi } \\
\cline { 2 - 3 } Petak Utama: V & & \\
\hline v1 (Ciherang) & 94,26 & $\mathrm{a}$ \\
v2 (Mekongga) & 95,20 & $\mathrm{a}$ \\
v3 (Inpari 33) & 93,48 & $\mathrm{a}$ \\
v4 (Cilamaya) & 92,05 & $\mathrm{a}$ \\
\hline Anak Petak: D & & \\
\hline d0(0 kg ha-1) & 92,54 & $\mathrm{a}$ \\
d1(150 kg ha & \\
d2(300 $\left.\mathrm{kg} \mathrm{ha}^{-1}\right)$ & 93,54 & $\mathrm{a}$ \\
d3(450 $\left.\mathrm{kg} \mathrm{ha}^{-1}\right)$ & 94,25 & $\mathrm{a}$ \\
\hline
\end{tabular}

Keterangan: Angka rata-rata perlakuan yang ditandai dengan huruf yang sama berbeda tidak nyata menurut Uji beda nyata terkecil (BNT) pada taraf nyata $5 \%$.

Bulir-bulir yang tidak terisi penuh akan menghasilkan gabah hampa. Oleh karena itu, persentase gabah hampa atau persentase gabah berisi juga merupakan komponen hasil yang utama. Persentasi gabah isi sangat menentukan potensi hasil maksimum suatu varietas padi. Hasil fotosintat (karbohidrat) dalam batang dan daun, dan translokasinya serta akumulasinya dalam gabah sangat menentukan tingkat pengisian gabah. Daun yang tegak dan sempit merupakan daun yang dapat menerima sinar matahari dari pagi sampai sore atau efisien dalam penangkapan sinar untuk proses fotosintesa. Sedang daun yang tebal dan hijau tua menandakan mempunyai banyak klorofil sehingga menghasilkan fotosintat; dan daun yang tidak cepat luruh fotosintat akan dihasilkan sampai menjelang panen. Cabang primer malai dapat menghasilkan butir gabah besar.

\section{d. Bobot GKP Per Rumpun}

Berdasarkan hasil analisis data menunjukkan bahwa terjadi interaksi antara varietas dosis pupuk $\mathrm{P}$ terhadap bobot GKP per rumpun, disajikan pada Tabel 6 .

Tabel 6. Pengaruh Takaran Pupuk P terhadap Bobot GKP Per Rumpun pada Beberapa Varietas Tanaman Padi (Oryza Sativa L.) .

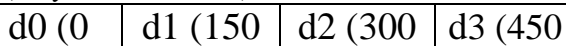

Taraf \begin{tabular}{l|l|l|l}
$\left.\mathrm{kg} \mathrm{ha}^{-1}\right)$ & $\left.\mathrm{kg} \mathrm{ha}^{-1}\right)$ & $\left.\mathrm{kg} \mathrm{ha}^{-1}\right)$ & $\left.\mathrm{kg} \mathrm{ha}^{-1}\right)$ \\
\hline
\end{tabular} -- Gram/rumpun--

v1 (Cihe 320,62 a 364,07 A 445,92 b 379,04 a

\begin{tabular}{|c|c|c|c|c|}
\hline rang) & A & A & B & $\mathrm{AB}$ \\
\hline
\end{tabular}

\begin{tabular}{ccccc} 
ongga) & A & B & C & A \\
\hline
\end{tabular}

v3 (Inpa301,57 a 391,65 A 383,62 a 339,67 a

\begin{tabular}{ccccc} 
ri 33) & $\mathrm{A}$ & $\mathrm{B}$ & $\mathrm{B}$ & $\mathrm{AB}$ \\
\hline
\end{tabular}

v4 (Cila 311,74 a 352,52 A 392,92 a 541,42 b

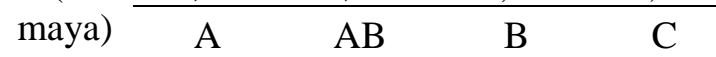

Keterangan: Angka rata-rata perlakuan yang ditandai dengan huruf yang sama pada tiap kolom (huruf kecil) dan tiap baris (huruf kapital) berbeda tidak nyata menurut Uji beda nyata terkecil (BNT) pada taraf nyata 5\%.

Berdasarkan Tabel 6, menunjukkan bobot GKP tertinggi didapat oleh perlakuan v2d2 (varietas Mekongga - dosis pupuk P 
$300 \mathrm{~kg} \mathrm{ha}^{-1}$ ) yang berbeda nyata dengan perlakuan v1d0 (varietas Ciherang tanpa dosis pupuk P), v1d1 (varietas Ciherang dosis pupuk P $150 \mathrm{~kg} \mathrm{ha}^{-1}$ ), v1d2 (varietas Ciherang - dosis pupuk P $300 \mathrm{~kg} \mathrm{ha}^{-1}$ ), v1d3 (varietas Ciherang dengan dosis pupuk $\mathrm{P}$ $450 \mathrm{~kg} \mathrm{ha}^{-1}$ ).

Pada sample v2d0 (varietas Mekongga tanpa dosis pupuk P) v2d1 (varietas Mekongga dengan dosis pupuk $\left.\mathrm{P} 150 \mathrm{~kg} \mathrm{ha}^{-1}\right)$, v2d3 (varietas Mekongga dengan dosis pupuk $\mathrm{P} 450 \mathrm{~kg} \mathrm{ha}^{-1}$ ), v3d0 (varietas Inpari 33 tanpa dosis pupuk P), v3d1 (varietas Inpari 33 dengan dosis pupuk $\mathrm{P} 150 \mathrm{~kg} \mathrm{ha}^{-1}$ ), v3d2 (varietas Inpari 33 dengan dosis pupuk P $300 \mathrm{~kg} \mathrm{ha}^{-1}$ ) v3d3 (varietas Inpari 33 dengan dosis pupuk P $450 \mathrm{~kg} \mathrm{ha}^{-1}$ ), v4d0 (varietas Cilamaya Muncul tanpa dosis pupuk P), v4d1 (varietas Cilamaya Muncul dengan dosis pupuk P $150 \mathrm{~kg} \mathrm{ha}^{-1}$ ) dan $\mathrm{v} 4 \mathrm{~d} 2$ (varietas Cilamaya Muncul dengan dosis pupuk P $300 \mathrm{~kg} \mathrm{ha}^{-1}$ ) tetapi tidak berbeda nyata dengan perlakuan v4d3 ((varietas Cilamaya Muncul dengan dosis pupuk $\mathrm{P}$ $450 \mathrm{~kg} \mathrm{ha}^{-1}$ ).

Hasil terkecil didapat pada tanaman (varietas Ciherang, Mekongga, Inpari 33 dan Cilamaya Muncul) yang tidak diberikan pupuk $\mathrm{P}$. Hal ini sesuai dengan penelitian Saragih (2005) bahwa pemberian pupuk P mampu meningkatkan tinggi tanaman, bobot gabah, dan bobot jerami padi. Lebih jelas Ardi et al. (1986) menegaskan bahwa pupuk $\mathrm{P}$ berpengaruh nyata terhadap pertumbuhan dan hasil tanaman.

\section{e. Hasil GKP Per Petak}

Berdasarkan hasil analisis data menunjukkan bahwa tidak terjadi interaksi antara varietas dengan dosis pupuk $P$ terhadap hasil GKP per petak dengan hasil analisis efek mandiri masing-masing pengaruh perlakuan, disajikan pada Tabel 7.

Menunjukkan Varietas Mekongga (v2) merupakan varietas dengan hasil GKP tertinggi dan berbeda nyata dengan varietas Inpari 33 (v3) dan varietas Cilamaya
Muncul (v4), tetapi tidak berbeda nyata dengan varietas Ciherang (v1). Pada anak petak penggunaan dosis pupuk $\mathrm{P}(\mathrm{d} 1, \mathrm{~d} 2$ dan d3) memperlihatkan adanya pengaruh terhadap peningkatan hasil GKP per petak dibandingkan dengan perlakuan tanaman tanpa penambahan pupuk $\mathrm{P}$ (d0) dapat dilihat pada tabel dibawah ini.

Tabel 7. Pengaruh Takaran Pupuk P terhadap P Tersedia Tanaman pada GKP Per Petak Beberapa Varietas Tanaman Padi (Oryza Sativa L.)

\begin{tabular}{|c|c|c|}
\hline \multirow{2}{*}{ Perlakuan } & \multicolumn{2}{|c|}{ Hasil Per Petak } \\
\hline & \multicolumn{2}{|c|}{--- kg --- } \\
\hline \multicolumn{3}{|l|}{ Petak Utama: V } \\
\hline v1 (Ciherang) & 14,74 & $\mathrm{bc}$ \\
\hline v2 (Mekongga) & 15,17 & $\mathrm{c}$ \\
\hline v3 (Inpari 33) & 13,03 & $\mathrm{a}$ \\
\hline v4 (Cilamaya) & 14,38 & $\mathrm{~b}$ \\
\hline \multicolumn{3}{|l|}{ Anak Petak: D } \\
\hline $\mathrm{d} 0\left(0 \mathrm{~kg} \mathrm{ha}^{-1}\right)$ & 12,24 & $\mathrm{a}$ \\
\hline $\mathrm{d} 1\left(150 \mathrm{~kg} \mathrm{ha}^{-1}\right)$ & 14,87 & $\mathrm{~b}$ \\
\hline d2 (300 $\left.\mathrm{kg} \mathrm{ha}^{-1}\right)$ & 14,42 & $\mathrm{~b}$ \\
\hline $\mathrm{d} 3\left(450 \mathrm{~kg} \mathrm{ha}^{-1}\right)$ & 15,79 & $\mathrm{~b}$ \\
\hline $\begin{array}{l}\text { Keterangan: Angka } \\
\text { ditandai dengan } \\
\text { tidak nyata menuru } \\
\text { (BNT) pada taraf ny }\end{array}$ & $\begin{array}{l}\text { ta perlakua } \\
\text { ang sama } \\
\text { beda nyata } \\
\% \text {. }\end{array}$ & $\begin{array}{r}\text { yang } \\
\text { erbeda } \\
\text { erkecil }\end{array}$ \\
\hline
\end{tabular}

Pemupukan $\mathrm{P}$ memegang peranan penting dalam meningkatkan produksi tanaman, karena $\mathrm{P}$ berperan dalam berbagai aktivitas metabolisme tanaman. Namun dari pemupukan yang dilakukan hanya $15-20 \%$ pupuk $\mathrm{P}$ diberikan pada tanah sawah yang bisa diserap tanaman, (Basyarudin, 2001).

Sebagian besar P terfiksasi dalam tanah. Oleh karena itu, perlu usaha peningkatan efisiensi pemupukan. Salah satunya adalah dengan penggunaan pupuk $\mathrm{P}$ dengan dosis tinggi yang mampu merangsang pemecahan ikatan ikatan $\mathrm{P}$ dengan $\mathrm{Al}, \mathrm{Ca}$ dan $\mathrm{Mg}$ sehingga $\mathrm{P}$ yang semula tidak tersedia di dalam tanah menjadi tersedia bagi tanaman (Estiaty, 2014). 


\section{f. Bobot GKG Per Rumpun}

Berdasarkan hasil analisis data menunjukkan bahwa tidak terjadi interaksi antara varietas dengan dosis pupuk $\mathrm{P}$ terhadap jumlah gabah isi per malai dengan hasil analisis efek mandiri masing-masing pengaruh perlakuan disajikan pada Tabel 8 .

Tabel 8. Pengaruh Takaran Pupuk P terhadap Bobot GKG Per Rumpun pada Beberapa Varietas Tanaman Padi (Oryza Sativa L.)

\begin{tabular}{|c|c|c|}
\hline \multirow{2}{*}{ Perlakuan } & \multicolumn{2}{|c|}{$\begin{array}{c}\text { Bobot GKG Per } \\
\text { Rumpun }\end{array}$} \\
\hline & \multicolumn{2}{|c|}{--gram-- } \\
\hline \multicolumn{3}{|l|}{ Petak Utama: V } \\
\hline v1 (Ciherang) & 270,09 & $\mathrm{~b}$ \\
\hline v2 (Mekongga) & 306,63 & $\mathrm{bc}$ \\
\hline v3 (Inpari 33) & 265,84 & $\mathrm{a}$ \\
\hline v4 (Cilamaya) & 310,65 & $\mathrm{c}$ \\
\hline \multicolumn{3}{|l|}{ Anak Petak: D } \\
\hline $\mathrm{d} 0\left(0 \mathrm{~kg} \mathrm{ha}^{-1}\right)$ & 241,20 & $\mathrm{a}$ \\
\hline d1 $\left(150 \mathrm{~kg} \mathrm{ha}^{-1}\right)$ & 291,77 & $\mathrm{ab}$ \\
\hline $\mathrm{d} 2\left(300 \mathrm{~kg} \mathrm{ha}^{-1}\right)$ & 328,14 & $\mathrm{~b}$ \\
\hline $\mathrm{d} 3\left(450 \mathrm{~kg} \mathrm{ha}^{-1}\right)$ & 292,11 & $\mathrm{ab}$ \\
\hline \multicolumn{3}{|c|}{$\begin{array}{l}\text { Keterangan: Angka rata-rata perlakuan yang } \\
\text { ditandai dengan huruf yang sama pada tiap } \\
\text { kolom (huruf kecil) tidak berbeda nyata } \\
\text { menurut Uji beda nyata terkecil (BNT) pada } \\
\text { taraf nyata } 5 \% \text {. }\end{array}$} \\
\hline
\end{tabular}

Berdasarkan Tabel 8, menunjukkan bahwa efek mandiri pada petak utama penggunaan varietas tanaman padi yang berbeda memperlihatkan pengaruhnya terhadap hasil GKP per petak. Varietas Mekongga (v2) merupakan varietas dengan hasil GKP tertinggi dan berbeda nyata dengan varietas Inpari 33 (v3), tetapi tidak berbeda nyata dengan varietas Ciherang (v1) dan varietas Cilamaya Muncul (v4). Pada anak petak penggunaan dosis pupuk $\mathrm{P}(\mathrm{d} 1$, d2 dan d3) memperlihatkan adanya pengaruh terhadap peningkatan hasil GKP per petak dibandingkan dengan perlakuan tanaman tanpa penambahan pupuk $\mathrm{P}(\mathrm{d} 0)$.

Pada hasil GKG per petak juga tidak terjadi interaksi anatara varietas dengan dosis pupuk P. efek mandiri hanya terjadi pada petak utama, dimana varietas invari 33 (v3) berbeda nyata dengan varietas ciherang (v1), mekongga (v2) dan varietas cilamaya muncul (v4).

\section{Hasil GKG Per Petak}

Berdasarkan hasil analisis data menunjukkan bahwa tidak terjadi interaksi antara varietas dengan dosis pupuk $P$ terhadap hasil GKG per petak dengan hasil analisis efek mandiri masing-masing pengaruh perlakuan disajikan pada Tabel 9.

Tabel 9. Pengaruh Takaran Pupuk P terhadap Hasil GKG Per Petak pada Beberapa Varietas Tanaman Padi (Oryza Sativa L.)

\begin{tabular}{ccc}
\hline \multirow{2}{*}{ Perlakuan } & \multicolumn{2}{c}{ Hasil Per GKG Petak } \\
\cline { 2 - 3 } Petak Utama: V & & \\
\hline v1 (Ciherang) & 11,22 & $\mathrm{~b}$ \\
v2 (Mekongga) & 10,56 & $\mathrm{~b}$ \\
v3 (Inpari 33) & 9,19 & $\mathrm{a}$ \\
v4 (Cilamaya) & 11,18 & $\mathrm{~b}$ \\
\hline Anak Petak: D & & \\
\hline d0 (0 kg ha- & & $\mathrm{a}$ \\
d1 (150 kg ha-1) & 11,11 & $\mathrm{~b}$ \\
d2 (300 kg ha & 10,74 & $\mathrm{~b}$ \\
d3 (450 $\left.\mathrm{kg} \mathrm{ha}^{-1}\right)$ & 11,16 & $\mathrm{~b}$ \\
\hline
\end{tabular}

Keterangan: Angka rata-rata perlakuan yang ditandai dengan huruf yang sama berbeda tidak nyata menurut Uji beda nyata terkecil (BNT) pada taraf nyata $5 \%$.

Berdasarkan Tabel 10, menunjukkan bahwa efek mandiri pada petak utama penggunaan varietas tanaman padi yang berbeda memperlihatkan pengaruhnya terhadap hasil GKP per petak. Varietas Ciherang (v1), varietas Mekongga (v2) dan varietas Cilamaya Muncul (v4) berbeda nyata dengan varietas Inpari 33 (v3). Pada anak petak penggunaan dosis pupuk $\mathrm{P}$ tidak memperlihatkan ada pengaruh yang nyata terhadap peningkatan hasil GKG per petak. 
Potensi hasil suatu varietas padi ditentukan oleh empat komponen, yaitu jumlah malai persatuan luas, jumlah gabah per malai, persentase gabah isi dan berat 1000 butir gabah. Sifat-sifat dari VUB adalah: tinggi pendek-sedang $(100-130 \mathrm{~cm})$; umur sedang genjah-sedang (110-135 hari); anakan banyak (>18 batang); malai sedang (100-150 gabah/malai); daun pendek, mendatar-tegak, hijau sampai hijau-tua; responsif terhadap pemupukan nitrogen. Introduksi VUB diharapkan meningkatkan produksi 2-3 x lebih tinggi dibandingkan varietas yang ditanam sebelumnya. Hasil kajian Sirappa et al. (2007).

\section{Bobot 1000 Butir}

Berdasarkan hasil analisis data menunjukkan bahwa tidak terjadi interaksi antara varietas dengan dosis pupuk $\mathrm{P}$ terhadap bobot 1000 butir dengan hasil analisis disajikan pada Tabel 10 .

Tabel 10. Pengaruh Takaran Pupuk P terhadap Bobot 1000 Butir pada Beberapa Varietas Tanaman Padi (Oryza Sativa L.)

\begin{tabular}{ccc}
\hline \multirow{2}{*}{ Perlakuan } & \multicolumn{2}{c}{ Bobot 1000 Butir } \\
\cline { 2 - 3 } & \multicolumn{2}{c}{- gram -- } \\
\hline Petak Utama: V & & \\
\hline v1 (Ciherang) & 27,25 & $\mathrm{a}$ \\
v2 (Mekongga) & 27,40 & $\mathrm{a}$ \\
v3 (Inpari 33) & 27,15 & $\mathrm{a}$ \\
v4 (Cilamaya) & 27,32 & $\mathrm{a}$ \\
\hline Anak Petak: D & & \\
\hline d0 $\left(0 \quad \mathrm{~kg} \mathrm{ha}^{-1}\right)$ & 26,90 & $\mathrm{a}$ \\
d1 $\left(150 \mathrm{~kg} \mathrm{ha}^{-1}\right)$ & 27,34 & $\mathrm{a}$ \\
d2 $\left(300 \mathrm{~kg} \mathrm{ha}^{-1}\right)$ & 27,33 & $\mathrm{a}$ \\
d3 $\left(450 \mathrm{~kg} \mathrm{ha}^{-1}\right)$ & 27,54 & $\mathrm{a}$ \\
\hline
\end{tabular}

Keterangan: Angka rata-rata perlakuan yang ditandai dengan huruf yang sama berbeda tidak nyata menurut Uji beda nyata terkecil (BNT) pada taraf nyata $5 \%$.

Pada Tabel 10 tidak terjadi perbedaan yang nyata baik pada petak utama (varietas) maupun pada anak petak (pemberian dosis pupuk P). Bobot 1000 biji juga merupakan salah satu faktor komponen yang menentukan langsung terhadap hasil padi dan juga mempunyai korelasi positif. Terjadinya korelasi positif sebagai akibat gen-gen pengendali antara karakter yang berkorelasi sama-sama meningkat.

\section{Hasil GKG Per Hektar}

Hasil analisis statistik terhadap hasil GKG per hektar disajikan pada lampiran 24. Berdasarkan hasil analisis data menunjukkan bahwa tidak terjadi interaksi antara varietas dengan dosis pupuk $P$ terhadap hasil GKG per hektar dengan hasil analisis efek mandiri masing-masing pengaruh perlakuan disajikan pada Tabel 11.

Tabel 11. Pengaruh Takaran Pupuk P Terhadap Hasil GKG Per Ha pada Beberapa Varietas Tanaman Padi (Oryza Sativa L.)

\begin{tabular}{|c|c|c|}
\hline \multirow{2}{*}{ Perlakuan } & \multicolumn{2}{|c|}{ Hasil GKG Per Ha } \\
\hline & \multicolumn{2}{|c|}{-- ton-- } \\
\hline \multicolumn{3}{|l|}{ Petak Utama: V } \\
\hline v1 (Ciherang) & 5,03 & $\mathrm{~b}$ \\
\hline v2 (Mekongga) & 5,34 & $\mathrm{~b}$ \\
\hline v3 (Inpari 33) & 4,38 & $\mathrm{a}$ \\
\hline v4 (Cilamaya) & 5,33 & $\mathrm{~b}$ \\
\hline \multicolumn{3}{|l|}{ Anak Petak: D } \\
\hline $\mathrm{d} 0\left(0 \mathrm{~kg} \mathrm{ha}^{-1}\right)$ & 4,36 & $\mathrm{a}$ \\
\hline d1 $\left(150 \mathrm{~kg} \mathrm{ha}^{-1}\right)$ & 5,29 & $\mathrm{~b}$ \\
\hline d2 $\left(300 \mathrm{~kg} \mathrm{ha}^{-1}\right)$ & 5,11 & $\mathrm{~b}$ \\
\hline $\mathrm{d} 3\left(450 \mathrm{~kg} \mathrm{ha}^{-1}\right)$ & 5,31 & $\mathrm{~b}$ \\
\hline
\end{tabular}

Keterangan: Angka rata-rata perlakuan yang ditandai dengan huruf yang sama berbeda tidak nyata menurut Uji beda nyata terkecil (BNT) pada taraf nyata $5 \%$.

Berdasarkan Tabel 11, menunjukkan bahwa efek mandiri pada petak utama penggunaan varietas tanaman padi yang berbeda memperlihatkan pengaruhnya terhadap hasil GKG per hektar. Varietas Ciherang (v1), varietas Mekongga (v2) dan varietas Cilamaya Muncul (v4) berbeda nyata dengan varietas Inpari 33 (v3). Pada anak petak penggunaan dosis pupuk $\mathrm{P}$ tidak 
memperlihatkan adanya pengaruh nyata terhadap peningkatan hasil GKG per Ha.

Pada anak petak (dosis pupuk P) tidak terdapat perbedaan yang nyata dengan dosis pupuk $\mathrm{P}$ lainnya. Hal ini menunjukkan peningkatan dosis tidak selalu menyebabkan peningkatan penyerapan $\mathrm{P}$ oleh tanaman, tergantung pada kebutuhan tanaman itu sendiri dan bentuk $\mathrm{P}$ yang tersedia dari sumber P. Seperti dikemukakan Rosmarkam et al. (2002), bahwa kecepatan penyerapan hara dipengaruhi oleh kadar hara dalam tanaman, bila kadar hara ini rendah maka penyerapan unsur hara relatif lebih cepat demikian juga sebaliknya.

\section{Analisis $P$ pada Tanaman}

Dari hasil analisis P pada tanaman yang dilakukan di laboratorium kimia agro Lembang, diperoleh data kandugan $\mathrm{P}$ pada jerami dan serapan $P$ pada jerami.

\section{a. Serapan P dalam Jerami}

Berdasarkan hasil analisis data menunjukkan bahwa tidak terjadi interaksi antara varietas dengan dosis pupuk $P$ terhadap serapan $\mathrm{P}$ pada jerami dengan hasil analisis efek mandiri masing-masing pengaruh perlakuan disajikan pada Tabel 13. Menunjukkan bahwa efek mandiri hanya terjadi pada anak petak, penggunaan takaran dosis pupuk $\mathrm{P}$ berbeda memperlihatkan pengaruhnya terhadap hasil serapan $P$ jerami. Penambahan takaran dosis pupuk P pada tanaman (d1, d2 dan $\mathrm{d} 3$ ) memberikan hasil yang berbeda nyata dengan tanaman yang tidak diberikan pupuk $P(\mathrm{~d} 0)$.

Pemberian bakteri pelarut $\mathrm{P}$ pada pupuk Biost-P dapat meningkatkan konsentrasi $\mathrm{P}$ tanaman sebesar $19,23 \%$ pada fase vegetatif akhir. Hal ini relative sebanding dengan parameter $\mathrm{P}$ tersedia dimana pada fase vegetatif akhir, tingkat ketersediaan $P$ meningkat dan peningkatan ini diikuti dengan meningkat pula konsentrasi $\mathrm{P}$ tanaman. Peningkatan konsentrasi tersebut sebanding dengan pemberian inokulan Penicillium sp. Hal tersebut seperti yang telah disebutkan bahwa fungi lebih mampu bertahan pada $\mathrm{pH}$ rendah apabila dibandingkan dengan bakteri, selain itu sifat mutualisme fungi dapat mengoptimalkan serapan $\mathrm{P}$ tanaman sehingga konsentrasi $\mathrm{P}$ tanaman meningkat (Mehrvarz et al.,2008).

Tabel 12. Pengaruh Takaran Pupuk P terhadap Serapan P Tanaman pada Kandungan Jerami pada Beberapa Varietas Tanaman Padi (Oryza Sativa L.) .

\begin{tabular}{|c|c|c|}
\hline Perlakuan & \multicolumn{2}{|c|}{$\frac{\text { Serapan P dalam Jerami }}{--\mathrm{mg} / 100 \text { gram -- }}$} \\
\hline \multicolumn{3}{|l|}{ Petak Utama: V } \\
\hline v1 (Ciherang) & 10,96 & $\mathrm{a}$ \\
\hline v2 (Mekongga) & 10,45 & $\mathrm{a}$ \\
\hline v3 (Inpari 33) & 10,11 & $\mathrm{a}$ \\
\hline v4 (Cilamaya) & 9,51 & $\mathrm{a}$ \\
\hline \multicolumn{3}{|l|}{ Anak Petak: D } \\
\hline $\mathrm{d} 0\left(0 \mathrm{~kg} \mathrm{ha}^{-1}\right)$ & 8,21 & $\mathrm{a}$ \\
\hline $\mathrm{d} 1\left(150 \mathrm{~kg} \mathrm{ha}^{-1}\right)$ & 10,56 & $\mathrm{~b}$ \\
\hline $\mathrm{d} 2\left(300 \mathrm{~kg} \mathrm{ha}^{-1}\right)$ & 11,35 & $\mathrm{~b}$ \\
\hline $\mathrm{d} 3\left(450 \mathrm{~kg} \mathrm{ha}^{-1}\right)$ & 10,92 & $\mathrm{~b}$ \\
\hline
\end{tabular}

Keterangan: Angka rata-rata perlakuan yang ditandai dengan huruf yang sama berbeda tidak nyata menurut Uji beda nyata terkecil (BNT) pada taraf nyata $5 \%$.

b. Kandungan $\mathrm{P}$ dalam Jerami

Berdasarkan hasil analisis data menunjukkan bahwa tidak terjadi interaksi antara varietas dengan dosis pupuk $P$ terhadap kandungan $\mathrm{P}$ pada jerami dengan hasil analisis efek mandiri masing-masing pengaruh perlakuan disajikan pada Tabel 13.

Tabel 13 menunjukkan efek mandiri pada petak utama penggunaan varietas tanaman padi yang berbeda memperlihatkan pengaruhnya terhadap kandungan $\mathrm{P}$ pada tanaman. Varietas Ciherang (v1) dan varietas Mekongga (v2) berbeda nyata dengan varietas Inpari 33 (v3) dan varietas Cilamaya Muncul (v4). Pada anak petak penggunaan takaran dosis pupuk $\mathrm{P}$ memperlihatkan adanya pengaruh yang 
nyata terhadap peningkatan kandungan $\mathrm{P}$ dalam jerami, tanaman yang diberikan takaran dosis pupuk $\mathrm{P}(\mathrm{d} 1, \mathrm{~d} 2$ dan $\mathrm{d} 3$ ) memberikan hasil kandungan $\mathrm{P}$ yang lebih tinggi dibandingkan dengan yang tidak diberikan pupuk $P$.

Tabel 13. Pengaruh Takaran Pupuk P terhadap Kandungan $P$ Tanaman pada Beberapa Varietas Tanaman Padi (Oryza Sativa L.)

\begin{tabular}{|c|c|c|}
\hline Perlakuan & \multicolumn{2}{|c|}{$\frac{\text { Kandungan P dalam Jeram }}{--\% \text {-- }}$} \\
\hline \multicolumn{3}{|l|}{ Petak Utama: V } \\
\hline v1 (Ciherang) & 0,23 & $\mathrm{~b}$ \\
\hline v2 (Mekongga) & 0,24 & $\mathrm{~b}$ \\
\hline v3 (Inpari 33) & 0,20 & $\mathrm{a}$ \\
\hline v4 (Cilamaya) & 0,20 & $\mathrm{a}$ \\
\hline \multicolumn{3}{|l|}{ Anak Petak: D } \\
\hline $\mathrm{d} 0\left(0 \mathrm{~kg} \mathrm{ha}^{-1}\right)$ & 0,19 & $\mathrm{a}$ \\
\hline d1 $\left(150 \mathrm{~kg} \mathrm{ha}^{-1}\right)$ & 0,22 & $\mathrm{ab}$ \\
\hline d2 $\left(300 \mathrm{~kg} \mathrm{ha}^{-1}\right)$ & 0,24 & $\mathrm{~b}$ \\
\hline $\mathrm{d} 3\left(450 \mathrm{~kg} \mathrm{ha}^{-1}\right)$ & 0,24 & $\mathrm{~b}$ \\
\hline
\end{tabular}

Keterangan: Angka rata-rata perlakuan yang ditandai dengan huruf yang sama pada tiap kolom (huruf kecil) tidak berbeda nyata menurut Uji beda nyata terkecil (BNT) pada taraf nyata $5 \%$.

Kandungan P-total dalam jerami merupakan akumulasi dari berbagai sumber $\mathrm{P}$ yang dapat diserap oleh tanaman. Dalam percobaan ini sumber $\mathrm{P}$ yang ada adalah $\mathrm{P}$ berasal dari tanah dan dari pupuk Biost-P. Distribusi kandungan $\mathrm{P}$ dalam jerami dari sumber memperlihatkan komposisi kandungan $\mathrm{P}$ dalam jerami.

\section{SIMPULAN}

Berdasarkan hasil penelitian dan pembahasan yang telah diuraikan maka dapat ditarik kesimpulan sebagai berikut :

1. Terjadi interaksi antara pemberian takaran pupuk $\mathrm{P}$ terhadap hasil bobot gabah kering panen (GKP) per rumpun.

2. Bobot gabah kering panen (GKP) per rumpun maksimal sebesar 572,60 gram diperoleh melalui varietas mekongga dengan takaran pupuk P $300 \mathrm{~kg} \mathrm{ha}^{-1}$.

\section{SARAN}

Agar diperoleh hasil maksimal pada tanaman padi varietas Mekongga, maka dapat dilakukan takaran pemupukan $\mathrm{P}$ sebesar $300 \mathrm{~kg}$ ha- ${ }^{1}$ dan perlu penelitian lanjutan mengenai pemupukan $\mathrm{P}$ pada varietas lainnya agar diperoleh takaran pupuk $\mathrm{P}$ yang optimum untuk berbagai varietas unggul yang ada pada lahan yang sama musim yang berbeda.

\section{DAFTAR PUSTAKA}

Atman. 2010. Pengaruh sistem tanam bershaf dengan $P$-starter (shafter) pada padi sawah varietas Batang Piaman. Jurnal Stigma VoL. XIII No. 4, Oktober-Desember 2005. Faperta Universitas Andalas Padang; 579582.

Badan Pusat Statistik. 2014. Tanaman Pangan. Badan Pusat Statistik. Jawa Barat

Badan Pusat Statistik. 2015. Sensus Produksi Padi Nasional 2014. Badan Pusat Statistik. Jakarta.

Balai Besar Tanaman Padi. 2012. Artikel Varietas Unggul Baru. Subang Sukamandi. Subang.

Balai Penyuluhan Pertanian Lenteng. 2012. Identifikasi pengendalian dan peramalanhama penggerek batang padi.

Basyaruddin. 2001. Pengaruh Residu Pemupukan P Pada Beberapa Famili Andisols Terhadap Pertumbuhan, Hasil, Serapan P dan Cl Tembakau Deli Di Sumatera Utara. J. Agrista. 6(1):50-55. 
Breitler, J.C., V. Marfd, M. Royer, D. Meynard, J.M. Vassal, B. Vercambre, R.Frutos, J. Messeguer, R. Gabarra \& E. Guiderdoni. 2007. Expression of a Bacillus thuringiensis crylB synthetic gene protects Mediterranean rice against the striped stem borer. Plant Cell Rep. 19:1195-1202. Terjemahan Estiati. 2007. Transformasigenettka untuk Merakit Varietas Padi Tahan terhadap Hama Penggerek.

Casanova,D.J.Gourdian.,M.M.C. Former andJ.C.M. Withangen, 2002. Rice Yield Prediction From Yield Component and Limiting Faktors. Europ. J.Agronomy 17 : 41-61.

De Datta, S. K. 1981. Weed Control in rice in South and Southeast Asia. FFIC Book Series 20: 1-24. Philippines. Dalam artikel Identifikasi GulmaGulma Dominan Pada Pertanaman Padi Sawah dan Usaha Pengendaliannya di Kecamatan Samatiga Kabupaten Aceh Barat

Fagi, A.M, A.K. Makarim, dan M.O. Adnyana. 1990. Efisiensi pupuk pada tanaman pangan. Prosiding Lokakarya Nasional $V$ Efisiensi Penggunaan Pupuk. Cisarua, 12-13 Nopember 1990. p.145-155.

Gomez, A. K and A. A. Gomez. 1995. Prosedur Statistik untuk Penelitian Pertanian. (Terjemahan oleh Enang Sjamsudin \& Justika Baharsjah). UI Press. Jakarta.

Hasanuddin, 2007. Pengelolaan Tanaman Padi Terpadu Suatu Strategi Pendekatan Teknologi Spesifik Lokasi. Makalah Disampaikan pada Pelatihan Pengembangan Varietas Unggul Tipe Baru (VUTB) Fatmawati dan VUTB Lainnya 31 Maret - 3 April 2004, di Balitpa, Sukamandi.

Humaeda. 2009. Varietas unggul padi baru. http:// www.litbang.deptan.go.id/ artikel/one/241/pdf/
Makarim, E. Suhartatik, dan A. Kartohardjono. 2007. Hara Penting Pada Sistem Produksi Padi. Penelitian Balai Besar tanaman padi. Subang.

Moenandir, Jody dan Mudji Santoso, 2008. Pengaruh pencampuran herbisida dan persiapan lahan terhadap pertumbuhan dan hasil padi sawah. Universitas brawijaya, malang.

Pusat Penelitian Tanah. 1982. Term of Reference Survai Kapabilitas Tanah. Proyek Penelitian Pertanian Menunjang Transmigrasi. Pusat Penelitian Tanah, Bogor.

Rochayati, S. dan S. Adiningsih. 2002. Pembinaan dan pengembangan program uji tanah untuk hara $P$ dan $K$ pada lahan sawah. Dalam Prosiding Pengelolaan Hara P dan K pada Padi Sawah. Puslittanak. Bogor. p 9-37.

Suprihartono, Aan, A. Daradjat, Satoto, Beahaki, Hendarsih Suharto, Suprianto. 2009. Inovasi Teknologi Padi Mengantisipasi Perubahan Iklim Global Mendukung Ketahan Pangan. Buku 1. Seminar Nasional Padi.Balai besar penelitian tanaman padi.

Suryo Wiyono . 2007. Perubahan Iklim dan Ledakan Hama dan Penyakit Tanaman.Makalah disampaikan pada Seminar Sehari tentang Keanekaragaman Hayati Ditengah Perubahan Iklim: Departemen Proteksi Tanaman Fakultas Pertanian Institut Pertanian Bogor Kampus IPB Darmaga Bogor, swiyono2@yahoo.com

Suyamto 2010 Pengembangan Inovasi Pertanian. Pusat Penelitian dan Pengembangan Tanaman Pangan. Bogor. 